\title{
"We show that we are men": the Dominant Masculinity Profile of the Portoan Ultra-groups
}
Authors' contribution:
A) conception and design of the study
B) acquisition of data
C) analysis and interpretation of data
D) manuscript preparation
E) obtaining funding

\section{Daniel Seabra}

Fernando Pessoa University, Portugal

\section{KEYWORDS}

\section{ABSTRACT}

The ultra-groups that support football clubs have been present in Portugal since the 1970s. Despite this support, performed with many chants and choreographies, the ultra-groups are reported mostly due to violent situations caused by their members. Based on an investigation of four ultra-groups that support football clubs in Oporto that was performed through lengthy observation, interviews, and surveys, this text highlights the characteristics of the dominant masculine profile present in these ultra-groups. The dimensions that allowed for the outline of this profile arise from theoretical perspectives reflecting gender and masculinity as an explanatory dimension of the aggressive behavior of hooligans and ultra-group members. These were briefly dealt in this text. They are composed of key features resulting from research about gender and masculinity in the Portoan ultra-groups, enabling their outlines. The physical and verbal violence, leadership profile, body display, homophobic discourse, and gendered exclusion expressed in the words, chants, and iconography of the ultra-groups allow for the definition of the key characteristics of the aggressive dominant masculine profile present in these Portoan ultra-groups.

ultra-groups, hooligans, masculinity, gender

\section{Introduction}

The ultra-groups that are present in the football stadiums in Portugal are groups with their own names that regularly occupy the same bench areas with the intention of supporting the team that represents the club with which they identify themselves. To accomplish this, they sing different types of chants and raise flags, banners, and flagships in which many signs of support are displayed; they also use different materials to compose choreographies and messages that they exhibit in football stadiums (Pereira 2002, p. 41; Dal Lago \& De Biasi 1994, pp. 80-81).

These groups first appeared in Portuguese stadiums at the end of the 1970s, but it was during the following decade that they experienced a significant growth and all the clubs that competed for the main Portuguese championship were supported by an ultra-group. A careful look through the bench areas that have 
been occupied by ultra-groups in Portugal is sufficient to easily note that these are mainly composed of members of the male gender. In 1992, the Portuguese ultra-groups were 90\% male (Marivoet 1992, p. 147).

This obvious majority was also apparent in other countries. In 1991, an ultra-group from Naples included 92.6\% male members, and 84.2\% of Bologna's ultra-group members were also male (Zani \& Kirchler 1991, p. 10). Roversi (1992, p. 69) also registered a similar percentage (82.9\%) of male members. González (1996, p. 61) took into account the sociological analysis of high-risk football matches made by Duran to highlight that only about 15\% of Spanish ultra-group members present in stadiums during the 1992/1993 season were female. During the following season, of the 576 people who were to be penalized by the Comission Nacional contra la Violencia due to the actions they carried out, only 7 were women (González 1996, p. 61). The male gender frequency in French ultra-groups was mentioned by Mignon (2002, p. 69) and reaches 90\%. In the British context, it is also apparent that hooligans are typically male. The first major research on hooliganism was carried out by Harrington (1968, p. 14) and led to this conclusion.

\section{Theoretical approaches to masculinity and hooliganism}

The male gender supremacy in hooligans, as well as the dominance of males in the general public present at football matches, is a subject that has been targeted by a number of researchers. Hutchinson considered that during the 1970s, the football audiences present in stadiums were mainly white-collar specialized workers, salesmen, and local managers. According to this author, ladies were also present at football stadiums and unskilled workers were a minority during this decade. A decrease in ticket prices made it easier for underprivileged social classes to access these football fields, which led to diversified spectators in terms of the attending social classes (Hutchinson 1975, pp. 5-12). The research carried out by Vamplew (1979, pp. 142143) led to a similar conclusion about the demographics of the spectators present in English football fields at the end of the nineteenth century, though he suggests that the game was intended for working class audiences. It's precisely according to this progress that Mason explains the predominance of male spectators. This author sustains that the increase in working class audiences justifies the decrease in the number of women present at the football matches, as they would not have many opportunities to attend these football events if they were married to working class men and responsible for the house and family chores (Mason 1980, p. 153).

Returning to the male gender predominance among hooligans, it is important to stress that masculinity emerged quite early on as an explanatory dimension for the violent behavior that characterizes these groups. Harrington (1968, p. 15) considered it as a predisposing factor towards aggression. However, it should be underlined that the association between aggression and violence among the male gender is understood today as a social and ideological construction (Amâncio 2004, p. 20; Badinter 1993, pp. 39, 45). In fact, gender constitutes body markers from which an organized symbolic system has been built to establish the differences in roles and identities (Kaufmann 2005, p. 92). Hence, "the psychological, social and cultural differences between individuals of male and female gender" emerged (Giddens 2004, p. 109). These are the differences that determine the female and male genders, not a person's biological sex. Consequently, behavioral differences between men and women derive from gender and not from sex, since no biological determinism arises from the latter in order to allow for

"the understanding of the various ways of being between men and women, nor the huge

diversity of configurations that relationships between men and women assume in different social contexts" (Amâncio 2004, p. 9).

It's in this context that researchers have tried to comprehend hooliganism. Dunning (1992, p. 390) considered that the sport has the tradition of being "one of the most relevant male reserved areas, and for that reason, of potential importance in the running of patriarchal structures." This researcher also highlighted the mimetic aspect of football, which results from the representation of a simulated clash, thus making it possible for some repressed aggressiveness to arise (Dunning 1992, pp. 394-399). Bearing this in mind, as well as Hutchinson's previously mentioned explanation, football appears as a social field where aggression associated with a certain male profile is produced and spread (Bourdieu 2002b, p.111; Bourdieu 1999, pp. 43-45).

The predominance of male hooligans, as well as the behavior that bestows this status upon them, has thus been inferred by various researchers. After Harrington's allusion to the male gender, Taylor (1982b, p. 
142) also associated hooligans' aggressiveness with a masculine profile derived from youthful allegiance to the working class and its intrinsic culture. The importance of aggression in constructing male masculinity in the working classes was also advocated by Critcher (1980, p. 161).

On the other hand, Clarke (1978, pp. 38-43) pointed out that the presence of spectators at a football match demands a knowledge of unwritten social codes that are not only limited to football matches, but also cover the principle of territoriality and local identity, male hegemonic capacity, firmness, and the release of work pressure through the excitement caused by the match, bearing in mind their working class social status.

Sociologists from the University of Leicester have also conferred great relevance to the male gendered aggressive profile that is the product of a determined social configuration. In short, it is characterized by family socialization that is not always present, but where physical punishment and frequent conflicts are abundant, where the male figure exercises his power and authority through an aggressive and sometimes violent form. It is also characterized by street socializing habits created in suburban neighborhoods where peer groups with strong fighting skills grant leadership, especially in neighborhood conflicts (Dunning et al. 1992, pp. 355-388). King also highlighted the importance of a male style that emerged during the 1960s, linking it to the cultural change in the working class that occurred in the previous decade. For King (1995, p. 639), the increase of violence in football and the growth of hooliganism were both a consequence of these changes.

In turn, Armstrong (1998, pp. 13, 21, 155-158) acknowledged that the understanding of hooliganism should bear in mind a male gender profile characterized by alcohol consumption, the defense of their women's honor, involvement with various women, the segregation and distancing of women from locations that then become exclusively for those of male gender, mockery of homosexuality, and involvement in physical confrontations. Taking part in these aspects of hooliganism allows the contenders to gain credit and access the "macho" condition.

On the other hand, Campbell and Dawson (2001, pp. 72-73) saw an encouraging setting towards the creation and reproduction of male domination in football, as in the stands we are able to hear expressions of physical violence towards the opponents, as well as verbal abuse, sexual downgrading, and homophobia. Such violence can result from the match and the tension created around it, but it also results from an embedded habit (Bourdieu 2002a, p. 167) that reproduces itself and intensifies in the football context.

\section{Male predominance in Portoan ultra-groups}

The research carried out on the Portoan ultra-groups confirmed the trend towards a large predominance of members of the male gender. In an examination of the records of associated members of the four ultragroups explored, Alma Salgueirista clearly had a higher percentage of registered male members, with an average of $91 \%$, followed by the Super Dragões ultra-group with around 82.4\%. Lastly, the Panteras Negras registered a total of $76.9 \%$ male members. Considering the full scope of membership registered by these ultragroups, it is clear that $85.1 \%$ of their members are male.

It is important, though, to take into account what was formerly stated. It must be pointed out that it is gender - as a psychological, social, cultural, and ideological construction - that helps us to understand the behavioral differences, roles, and identities between men and women, not sex. In a social and cultural framework where hegemonic masculinity "is tainted by contradictions and has suffered multiple turmoil," as is referred to by Amâncio (2004, p. 27), football is highlighted as a refuge.

Hence, the research within the Portoan ultra-groups sought to verify whether these groups represent a social area of production and reproduction of a hegemonic male gender profile identified by aggression and related characteristics (Campbell \& Dawson 2001, pp. 72-73). The theoretical approaches referred to in this text will thus represent a benchmark for the analysis and meaning of masculinity in Portoan ultra-groups.

\section{Male leadership}

Statements made by some women belonging to the researched ultra-groups confirm this assumption. Some confessed their inhibition and fear of joining an ultra-group, as they consider them to be aggressive social settings and intended mainly for men. One of the interviewed women recalled "if I went to a football 
match, my mother would immediately protest because football is a man's thing." Another important indicator of this perception is the fact that many women joined ultra-groups only to accompany their boyfriends who were already members, rather than out of an individual motivation or initiative.

Apart from the predominance of male members, the research also disclosed the presence of hegemonic male characteristics marked by aggressiveness. In fact, the results of the questionnaire surveys and observations revealed that involvement in aggressive situations is almost exclusive to male members.

Just as Revilla (1996, p. 20), Buford (1994, p. 30), and Ferrando (1987, p. 7) pointed out, involvement in these situations is a means of access to status within the group. This idea was also present in the Portoan ultra-groups. One of the leaders confessed to having gained respect "in the muscular area." Another important leader said the following significant words about the importance of participating in violence in order to reach ultra-group leadership: "It's true that we have made many mistakes and that we used to break everything. But the reason Super Dragões are respected everywhere, it is due to the actions taken by the Ribeira kids." This leader also admitted that he was appointed by the president "because even inside the ultra-group, there seemed to be some fear of our group and I was the only one that could impose respect due to my different past in the Ribeira."

\section{Physical violence}

Reference to this aspect of the city is very important, since the field survey carried out revealed that violent behavior, as well as thefts, burglary, and vandalism, are, for the most part, undertaken by members from certain housing districts in Oporto, especially those associated with its 47 neighborhoods. These residential clusters grant housing for the under-privileged social classes. Here, groups of young neighbors are established. These groups create clusters in the Portoan ultra-groups. Many of these ultra-subgroups use the community name where they live. Portoan members acknowledge that members from these communities usually display the abovementioned behaviors. One of the interviewees said "We can't say it's only people from the neighborhoods, but most of them are." Another interviewed member assumed a more radical assessment and underlined that "It's mostly them, trying not to blame them all."

In fact, the research confirmed the theoretical relevance of the research carried out by sociologists from the University of Leicester. As has been shown in the text "Importance and Limitations of the Leicester Group Theory towards the Comprehension of Delinquent Behaviour of Ultra Groups of Oporto," the specific social configuration characterized and displayed by this group as an explanatory theory for hooliganism is also present is Portoan ultra-groups. ${ }^{2}$ Bearing in mind the fact that King (1995, p. 639) also foresaw the aggressive male gendered profile as a consequence of transformations taking place in the working class in the 1950s (which were also identified by the Leicester sociologists), and considering this as another reason for hooliganism, data related to Portoan ultra-groups confirm this author's perspective.

Therefore, an aggressive male gendered profile appears in the context of suburbanization with a social configuration that shows the characteristics mentioned by the Leicester sociologists, which have already been presented in this text. Although it is not the main reason that ultra-group members indicate as encouragement for their participation in violent situations, it must be stressed that some members say that when they are faced with such situations, "that one understands who is a MAN." Even other reasons more frequently referred by some authors as justifying the participation in violence are equally set within an aggressive masculinity profile.

The defense of the honor and identity of the group is one of the main reasons given by members of the Portoan ultra-groups to get involved in violence. One of them stated that "it's defending the area, the city, the

\footnotetext{
${ }^{1}$ The absence of women in Portoan ultra-group leadership is another sign of the assumed predominance of the male gender. However, the Super Dragões and Pantera Negras ultra-groups benefit a lot from the work of women. In the Portoan ultra-group, a woman was responsible for the administrative work, registering and responding to members and participating in all group activities. In the Boavista ultra-group, another woman took on an important role as an advisory resource to the board of directors of the ultra-group and conflict management. She also managed food care for the members of the group during journeys to other stadiums. Later, when the supporting class became a law enduring association, she was integrated into the committee.

${ }^{2}$ Read: Seabra, D. (2010). Importance and limitations of the Leicester group theory towards the comprehension of delinquent behaviour of ultra groups of Oporto. Physical Culture and Sport Studies and Research, 49, 78-84. See Bibliography.
} 
club... all of it. It's a question of honor. We always want to be on top." Another interviewed member recalled that "At a certain point we have to confront because it's not only the group that is involved, but also the club and the region." This defense of honor is a necessity to dominate the opponent and is highlighted by many researchers, equally extended to the defense of territory (Armstrong \& Harris 1991, p. 436; Armstrong 1998, pp. 234, 259; Giulianotti \& Armstrong 2002, p. 217; King 2001, pp. 572-573).

The field research confirmed that the ultra-groups have symbolic territories that cannot be invaded by opponent clubs or supporters. When this happens, violent conflicts may occur. An example of this was the conflict between the Super Dragões ultra-group and the ultra-groups that support Sport Lisboa e Benfica. One of the interviewed members reported that

"It was a genuine pitched battle (...) Manhunt. All Super Dragões waiting for them. And everyone, from Monte Aventino, from the walls throwing objects. (...). They were running away and we were right behind them. (...) We totally beat them up."

Stress relief from work is also a reason for violence mentioned by a significant number of Portoan ultragroup members. One of them said

"I go and watch an outside match and I'm in a war. (...) But it's good. A bloke relieves

the stress. At least, all the stress goes away and I can work the whole week quietly." Another one

mentioned that the violent situations "are moments that relieve the stress."

Statements of this kind confirm Kerr's $(1994$, p. 63) perspective, in which the violence carried out by hooligans provides a sense of freedom.

This defense of the honor of the Portoan ultra-groups and clubs and the defense of their territories, associated with physical endurance and stress release from work, constitute the elements of unwritten, implicit social codes, which Clarke (1978, pp. 38-43) pointed out as being associated with the working class experience. They are, therefore, elements to consider as part of the hegemonic male gendered profile with which they are associated

The body is also a boisterous symbol of masculinity associated with the image of bravery and physical endurance. It is common to see many group members standing bare-chested in the first rows of the stadium benches reserved for the ultra-groups. This can be interpreted as an exuberant demonstration and celebration of courage and bravery, especially when it is raining and/or very cold.

Rather than, and in opposition to the courage and bravery shown through engaging with violent beahviour and by standing bare-chested, fleeing from conflicts that occurred as a consequence of necessary self-defense, is viewed not only of a serious lack of solidarity but also of effeminate or "sissy" behaviour.

One woman suggested that the participation in violence was one of the main motivations for joining the ultra-group. Significant situations involving female elements in violence are not seen. On the contrary, female involvement was almost always directed towards appeasement. ${ }^{3}$

For the above reasons, it is clear that involvement in violence is a symbol linked with a domineering and aggressive male profile that is different from the female profile, non-violent and tending towards conflict moderation and appeasement.

Hence, it is important to note that some ultra-group members from these places base their behavior on correction principles. Instead, there are others who are not from the working class and who do not reside in these neighborhoods but practice the same acts, sometimes even more planned and thus more efficient. One of the interviewed confirmed this with the following statement:

\footnotetext{
3 The same does not happen where thefts are concerned. Even though these are predominantly committed by male individuals, we can also see female participation. One of them said "I stole with all the girls. (...) and if anyone wanted to buy tobacco, they had to give us the money. We'd go through the shelves and we'd fill our bags and pay for the tabacco." This woman added "It works well with the help of the girls. I can say I belonged to them becuse I helped a lot, because a girl carrying something that others robbed is less theft than a guy leaving with the goods." In a book that was written about him, a leader of one of the studied ultra-groups referred to the role women assumed when hiding thefts and the need he had to hide things stolen at the duty-free shop at the Manchester airport: "Immediately I saw lots of people, most of them women, going to the toilet with their bags, to hide them" (Macaco cit. in Bastos 2005, p. 144)
} 
“We have a lot of good boys, 'betinhos,' as they are called, and they are much worse.

They're sneaky. They do it quietly."

It's in this aspect that Armstrong's perspective about masculinity exceeds this associative limitation between this social class and the working class. The characteristics that Armstrong highlighted and that are mentioned in the present text allow for the description of a dominating male gendered profile that is transversal to social classes and that is present in the Portoan ultra-groups.

\section{Consumption of alcoholic beverages}

One of the most obvious aspects of membership in the ultra-groups is the consumption of alcoholic drinks. When clubs supported by their ultra-clubs play at home, their members meet at cafés adjacent to the stadiums two to three hours before the match begins and consume great quantities of beer. When the matches are played at the opponent's stadium, these groups carry a huge quantity of beer, which is consumed during the journey. One of the interviewees recalled: "we took crates of beer and played cards all night. We got there without any beer." Sometimes some of the group members end up being forbidden to enter the stadiums because of their drunken state. The ultra-group Alma Salgueirista likes to show off their alcohol consumption and is known for it. One of their members said

"Whether we lose or win, we get into a hell of a drunken stage. A bloke gets to a point where you don't know what you are drinking anymore. Maybe we associate it with wine already."

Another one highlighted that

"It's no coincidence that Salgueiros is known for being the demijohn wine."

\section{Sexual disqualification and homophobia}

Sexual comments about women are another common characteristic of ultra-groups. Photos of naked women and a discourse that refers to women as sexual objects is also very present. In addition, the homophobic discourse often associated with insulting vocabulary and includes verbal aggression is also present in the Portoan ultra-groups and is one of the characteristics of the male gender profile emphasized by Armstrong. It is through homophobia and sexual segregation that the opponent is diminished. An example of this is how Portoan ultra-groups refer to the "No Name Boys," one of Sport Lisboa and Benfica's ultra-groups and the main rival of Futebol Clube do Porto, as the "No Name Gays." On the other hand, the ultra-group "Insane Guys," supporting Vitória de Guimarães and thus the main rival of the Panters Negras ultra-group, is also called "Insane Gays."

Insults and homophobic segregation are, above all, present in chants, but also on clothes worn by some ultra-group members. On one of the chants sung by Super Dragões includes the following line: "Shove it up your ass and don't fight about it. No Name Gays, motherfuckers." Another is sung with the following words: "Oh these are the Super Dragões, Ultras forever. Anxious to fuck the No Name Gays until they die."

Within the context of the group rivalry with Futebol Clube do Porto, the ultra-group Panteras Negras also chant: "Andrade is a bighead. He disguised himself as a dragon. He spits fire through the mouth but it is the ass gives him the hard on." Another chant is "Oporto is gay, Boavista, bigheaded. Oporto lets down his pants and Boavista shoves it up his ass."

Where clothing is concerned, the dragon is considered the most important symbol of the Futebol Clube do Porto's badge, and the eagle is the most important symbol for Sport Lisboa e Benfica's badge. It's in the sexual discrimination and submission logic that one can understand the image of the dragon's continuing sodomy of the eagle. The presence of images showing off the middle finger, which represents male genitals and its phallic extent, is also frequent iconography in the researched ultra-groups.

The homophobic discourse seems to contain a certain paradox. The opponent is accused of being "gay" and homosexuality is the reason for stigma and shame. However, the iconography of the ultra-groups includes representative images of a sexual relationship with the opponent, which implies the "gay" status and, consequently, the stigma with which it is considered by the ultra-group members. This type of iconography seems to represent a supremacy relationship where the opponent is excluded and humiliated by sexual 
submission. This can be understood as one more dominant male gendered profile found in Portoan ultragroups.

\section{Conclusion}

Like many other studies carried out on ultra-groups and hooliganism, this study about Portoan ultragroups also confirmed the prevalence of a hegemonic male gendered profile with an aggressive tendency and multiple dimensions.. For such is not the fact that the majority of the Portoan groups is constituted by males that is a sufficient condition, being instead their behavior as part of the masculinity profile already referred to. Their participation in situations of violence is one of their main characteristics. They are formed, for the most part, by male members who come from disadvantaged sectors of the working class and live in some social housing districts of the city of Oporto, where social layouts with identical characteristics to the ones mentioned by the sociologists from the University of Leicester are found. This often includes weak socialization in nonattending families who resort to physical punishment, where the husband is the authority model and exerts his authority in an aggressive, even violent way, gaining respect for his fighting capacity.

Other ultra-group members, although not connected with these habitational zones and settings, also demonstrate this male profile. This has also been seen not only in physical confrontations but through the display of the male body in an effort to show courage. Alcohol consumption, verbal violence, and iconography are also used, as well as chants and speeches with homophobic content. The absence of women in leadership roles is another indicator of male hegemony.

Lastly, and following Campbell and Dawson's argument referred to in this text, the data collected and its interpretation in the light of the theoretical perspectives developed by several researchers who have studied hooliganism and football ultra-groups, the possibility of football being a social space where the production and reproduction of male dominance takes place through the valuing of an hegemonic masculinity is reinforced.

\section{REFERENCES}

Amâncio, L. (org.) (2004), Aprender a ser Homem. Construindo masculinidades /Learn to be a Man. Building masculinities/. Lisboa: Livros Horizonte.

Armstrong, G. (1998). Football Hooligans: Knowing the Score. Oxford: Berg.

Armstrong, G. \& Harris, R. (1991), Football Hooliganism: theory and evidence. The Sociological Review, vol. 39, n. ${ }^{\circ}$, 427- 458.

Badinter, E. (1993), XY. A identidade Masculina /XY. The masculine identity/. Porto: Edições Asa.

Bastos, F. (2005), Fernando Madureira. O Líder/Fernando Madureira. The leader/. Vila Nova de Gaia: O Gaiense.

Bourdieu, P. (1999), A dominação Masculina /The male domination/. Oeiras: Editora Celta.

Bourdieu, P. (2002b), Questions de Sociologie / Questions of Sociology/. Paris: les Éditions de Minuit.

Buford, B. (1994), Entre os vândalos. O futebol e a violência /Among the thugs. The football and violence/. Porto: Edições Asa.

Campbell, B. \& Dawson. A. (2001), Indecent exposures, men, masculinity and violence, in M. Perryman (Ed.), Hooligan Wars. Causes and effects of football violence (pp. 62-76). Edinburg \& London: Mainstream Publishing.

Clarke, J. (1978). Football and working class fans: tradiction and change. In R. Ingham, S. Hall, J. Clarke, P. Marsh \& J. Donovan (Eds.), 'Football Hooliganism' The wider context (pp. 37-60). London: Inter-Action Inprint.

Critcher, C. (1980). Football since the war. In J. Clark (Ed.), Working-Class Culture. Studies in History and Theory (pp. 161-184). London: Hutchinson \& Co.

Dal Lago, A \& Rocco, B. (1994), Italian football fans: culture and organization. In R. Giulianotti et al (Eds.), Football, Violence and Social Identity (pp. 73-89). London and New York: Routledge.

Dunning, E. (1992), O desporto como uma área masculina reservada: notas sobre os fundamentos sociais na identidade masculina e as suas transformações / Sport as a reserved masculine area: notes on the social foundations of masculine identity and its transformations/. In N. Elias, A busca da Excitação / The quest for excitement/ (pp. 389-412). Lisboa: Difel. 
Ferrando, M. (1987), Interpretações sociológicas da violência no desporto /Sociological interpretations of violence in sport/. Lisboa: Ministério da Educação e Cultura - Direcção Geral dos Desportos.

Giddens, A. (2004), Sociologia /Sociology/. 4th ed, Lisboa: Fundação Calouste Gulbenkian.

Giulianotti, R. \& Armstrong, G. (2002), Avenues of contestation. Football hooligans running and ruling urban spaces.», Social Anthropology. The journal of the European Association of Social Anthropologists, Vol. 10, Part 2, $211-238$.

González, J., (1996), El Vandalismo en el Futbol. Una Reflexión sobre la Violencia en la sociedad moderna / Vandalism in football. A reflection on violence in modern society/. Madrid: Gymnos Editorial.

Harrington, J. (1968), Soccer Hooliganism, Bristol, John Wright \& Sons.

Hutchinson, J. (1975), «Some Aspects of Football Crowds Before 1914.». In The Working Class and Leisure, paper $n^{\circ}$ 13 (pp. 1-19) Proceedings of the Conference for the Study of Labour History, University of Sussex.

Kerr, J. (1994). Understanding Soccer Hooliganism. Buckingham: Open University Press.

Marivoet, S. (1992), Violência nos espectáculos de futebol. /Violence in football matches. In Sociologia. Problemas $e$ práticas /Sociology, problems and practices/. 12, (pp. 137-153), Lisboa: Centro de Investigação e Estudos de Sociologia. Departamento de Sociologia ISCTE.

Mason, T. (1980), Association Football English Society 1863-1915. Sussex: The Harvester Press.

Mignon, P. (2002), Another side to French excepcionalism: football without hooligans?. In E. Dunning et al (Eds), Fighting Fans, Football Hooliganism as a World Phenomenon, (pp. 62-74). Dublin: University College Dublin Press.

Pereira, L. (2002). Dicionário do Futebol. Manual do Adepto /Football dictionary. Handbook of the fan/. Lisboa: Booktree.

Revilla, T. (1996). Ultras e skinheads: La juventud visible. Imágenes, estilos y conflitos de las subculturas juveniles en España/Ultras and skinheads. The visible youth. Images, styles and conflicts of juvenile subcultures in Spain/. Oviedo: Ediciones Nobel.

Roversi, A. (1992), Calcio, Tifo e Violenza. Il teppismo calcistico in Itália /Football, Tifo and violence. Football hooliganism in Itália. Bologna: Società Editrice Il Mulino.

Seabra, D. (2010), Importance and Limitations of the Leicester Group Theory towards the Comprehension of Delinquent Behaviour of Ultra Groups of Oporto. Physical Culture and Sport Studies and Research, Volume XLIX, 78-84.

Taylor, I. (1982b), Soccer Consciousness and Soccer Hooliganism. In Stanley Cohen, Images of deviance, (pp. 134-164). Harmondsworth: Penguin.

Vamplew, W. (1979), Ungentlemanly Conduct: The Control of Soccer-crowd Behaviour in England, 1888-1914. T. Smouth, The Search for Wealth and Stability, (pp. 139-154, Londres: Macmillan.

Zani, B. \& Kirchler, E. (1991), When Violence Overshadows the Spirit of Sporting Competition: Italian Football Fans and theis Clubs. Journal of Community \& Applied Social Psychology, Vol. I, 5-21.

\section{AUTHOR'S ADDRESS: Daniel Seabra}

Fernando Pessoa

University Human and Social Sciences Faculty

Praça 9 de Abril, n. ${ }^{\text {o }} 3494249$ - 004 Oporto Portugal

E-mail: das@ufp.edu.pt

Received: 19 May 2018 ; Accepted: 2 July 2018 